\title{
The dehumanizing metaphors in the culture of Acehnese in Indonesia
}

\author{
Jarjani Usman $^{1^{*}}$ and Yunisrina Qismullah Yusuf ${ }^{\mathbf{2}}$ \\ ${ }^{1}$ Department of English Language Education, Faculty of Education and Teacher Training, Universitas Islam \\ Negeri Ar-Raniry, Jalan Syeikh Abdul Rauf, Darussalam, Banda Aceh 23111, Indonesia \\ ${ }^{2}$ Department of English Education, Faculty of Teacher Training and Education, Universitas Syiah Kuala, \\ Jalan T. Nyak Arief, Darussalam, Banda Aceh 23111, Indonesia
}

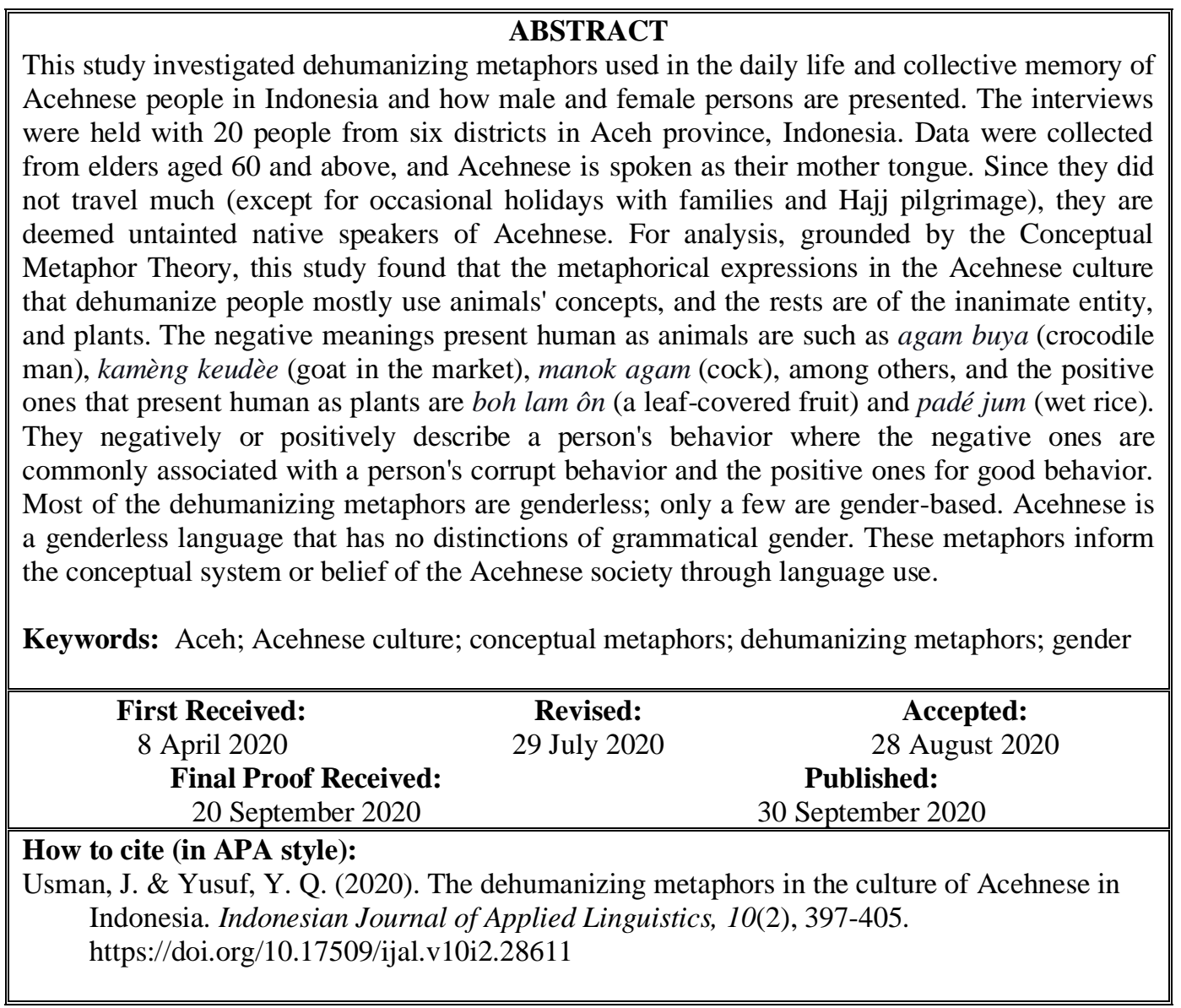

\section{INTRODUCTION}

Metaphors exist in any language, including the Acehnese language spoken in Aceh, an Indonesian province situated in Sumatera Island's northern tip. The use of metaphors is intended to facilitate understanding complex ideas, communicating efficiently, and persuading others (Thibodeau et al., 2019). Lakoff and Johnson (1980, p. 5) define metaphor as "understanding and experiencing one kind of thing in terms of another thing." In the same vein, Adams et al. (2017) define it as the use of the abstract concept to describe the abstract concept.
For instance, the abstract concept of "time" is presented with a domain of spatial movement, which is more familiar to the audience (Jamrozik et al., 2016).

To better understand metaphors, it is worth differentiating metaphorical meaning from the literal meaning. Concerning this, Steen (2002, p. 389) maintains that "the literal meaning is direct, concrete meaning; metaphorical meaning is indirect abstract meaning." For instance, 'war' as a (real) war and 'argument' as a war. The former is the literal meaning, whereas the latter is a metaphorical

\footnotetext{
* Corresponding Author

Email: jarjani@ar-raniry.ac.id
} 
meaning. Besides, understanding the metaphor should not be confused with a simile. A simile is metaphor-like; however, it is commonly used with 'as, ' 'like, ' and 'than' (Fata, Yusuf, \& Sari, 2018). A simile is used to ease in understanding the concept analogically. However, a metaphor can be changed into a simile if the word 'like' is added: lagèe agam buya(like a crocodile man). Regarding similes in the Acehnese language, Azwardi (2012) found many similes that contain animals in Acehnese, such as lagèe bu drop daruet (like a monkey catching the grasshoppers, lagèe leumo ta-peuteungoh lam mon (like a cow pulled out from the well), et cetera. Again, in his simile examples, lagèe 'like' is used, while metaphor uses 'is,' 'are,' and 'were' (Keraf, 2004)

The use of animals and other things to refer to human beings in metaphors in many cultures is called dehumanizing metaphors. Dehumanization refers to "the denial of a person's humanness" (Haslam, 2006, as cited in Adams et al., 2017, p. 247). For instance, to express a man's behavior as a womanizer, agam buya (a crocodile man) in Acehnese. However, the use of animals or other things to dehumanize people depends on the culture people embrace. That is why some of the metaphors are general that people of a different culture can understand them, but some are culturally specific metaphors (Lakoff \& Johnson, 1980), which are only used and understood by some of those who share the Acehnese culture. However, even though they are culturally related, some people are unaware of the metaphors used or exist in their utterances (Lakoff, 1995). Therefore, it is crucial to analyze metaphors used or created by society as they serve many purposes in life.

Many theories have been developed to identify and analyze metaphors, such as the Conceptual Metaphor Theory (CMT) by Lakoff and Johnson (1980). In this theory, a metaphor can be understood from three elements that comprise the source domain, target domain, and a mapping (Lakoff \& Johnson, 1980; Thibodeau et al., 2017). The source domain is metaphor use, the target domain is the concept of a thing, and mapping is the characteristics of both source and target domains. In the example of 'life is a journey', for instance, 'life' is the target domain, and 'journey' is the source domain. From both domains, a mapping of properties of the source and target domains can be made in the following way: 'life' = journey; 'we' = travelers; 'destination' = the end to be reached. Hence, the metaphor shapes the thoughts of people about life (Su, 2002). Therefore, based on the theory, metaphors are "implicit in the sense that they are embedded in the concepts, so that people involved in communication are not usually aware that expressions they use have a metaphorical origin" (Daane et al., 2018).
According to Lakoff and Johnson (1980), cognitive metaphor is based mainly on two sources: the environment where we all live and the culture. Environmental metaphors are the metaphors that "have to do with our physiological makeup or general truths present everywhere. Those metaphors appear to be nearly universal" (Lowery, 2013, p. 13), which people understand regardless of their culture. On the contrary, culture-based metaphors are those that "are culturally motivated...reflect the particular worldview of a given culture or subculture" (Lowery, 2013). The culture-based metaphors are not easy to understand because they use animals or things close to or known in a specific culture in a country.

The use of animals or other things in metaphors to dehumanize people is vivid in the Acehnese culture. In Aceh, people use various animals, foods, and other non-human things as metaphors to negatively or positively describe a person's behavior. However, some of the Acehnese language speakers, especially the millennials, do not understand the meanings of dehumanizing metaphors. This is a factor that may remove the metaphorical expressions from the collective memory of the Acehnese society. Hence, studying the Acehnese metaphors is essential to understand the dehumanizing meanings in the Acehnese language. And, studies on metaphors used by society are proven to be an essential language maneuver because they reflect the perceptive source of society's belief ( $\mathrm{Su}, 2002)$.

Several studies on the dehumanizing metaphorical language in many parts of the world have been carried out (e.g., Barasa \& Opande, 2017; Musolff, 2015; O'Brien, 2009; Prażmo, \& Augustyn, 2020; Usman, 2017). Musolff (2015), for instance, analyzed the dehumanizing metaphors used in British debates on immigrants. It showed that immigrants were negatively presented in the debates by using 'parasites,' 'leeches,' or 'bloodsuckers.' Meanwhile, O'Brien (2009) analyzed the social policy regarding the use of dehumanizing metaphors. The analysis reveals that the policy negatively framed workers; this suggests that researching metaphors is crucial for uncovering metaphors that promote inequality and discrimination in society. Moreover, the research by Li (2019) studied the representation of women in advertisements presented in Cosmopolitan, a leading women's magazine. It explored the gender ideology that dehumanizes women by studying the visual and linguistic codes deployed in the magazine. The results showed two major dehumanizing metaphors, where 'women are objects' and 'women are animals.' In the meantime, 'beings are things' metaphors it the main instrument in constructing the dehumanizing discourse and ideology.

In the Acehnese culture, Usman (2017) has explored the use of political metaphors during the 
pre-public elections in Aceh province. The results showed that during the public elections, politicians in Aceh used various metaphors, including the dehumanizing ones, in the politicians' regimes' propaganda. However, this research did not analyze the gendered-based dehumanizing metaphors used in the Acehnese culture; therefore, this study is carried out to fill in the gap. It intends to explore the dehumanizing metaphors used in the Acehnese language by society. The results are expected to highlight the inequality and discrimination embedded in the metaphors in the Acehnese social interactions. Furthermore, these metaphors further inform the conceptual system or belief of the Acehnese society through language use.

\section{METHOD}

This study employed qualitative design as it critically analyses the dehumanizing metaphors in the Acehnese culture. It attempted to unearth the meanings embedded in the metaphors commonly used in the Acehnese culture. This critical analysis can deconstruct the metaphorical words and expressions that seem 'normal' or unquestioned by Aceh's people.

To collect data, interviews and focused group discussions were employed. The interviews were done informally to enable the respondents to talk freely. The interview started with probing questions such as "If jamok di luwa keuleumbu' mosquitos outside the mosquito net' is used to mean the people outside the system, is it correct? What are other expressions in the Acehnese language that uses animal, plant, and so forth that refer to a person?" The interviews were done with 20 people from six districts in Aceh province, Indonesia. Representatives from the six districts where the Acehnese language is mostly spoken are crucial to collect comprehensive data from different places in Aceh. They are elders aged 60 and above, and Acehnese is spoken as their mother tongue. Since they did not travel much (except for occasional holidays with families and Hajj pilgrimage), they are deemed untainted native speakers of Acehnese.

Additionally, focus group discussions were held twice. The first one was arranged and done with 14 out of the 20 informants; meanwhile, the second one with six out of the 20 informants who are also academics at Universitas Islam Negeri ArRaniry in Banda Aceh. This way was done to validate the meanings of the metaphors. Both the interviews and FGDs were recorded using a handphone.

In analyzing the data recorded, the steps proposed by Creswell (2014) were followed. The first step was to organize the raw data (i.e., the recorded data) by transcribing them. The second step was to organize and prepare data for analysis. After the transcriptions were done, the informants' answers or explanations were categorized based on the themes that emerged; they were metaphors based on the concepts of animals, inanimate entity, and plants. The third step was reading through the data again to double-checked their precision. The fourth step was coding the data based on the three categories. Finally, the last step was to interpret the themes' meaning to be displayed narratively in the paper.

\section{FINDINGS}

Tables 1-3 display the Acehnese metaphors that dehumanize human beings based on the data. The data revealed that these metaphors are derived from three concepts: animals, inanimate entity, and plants.

\section{The person as animal metaphors in Acehnese}

There are some 19 metaphors associated with a person as animals in Acehnese, and they are illustrated in Table 1 (the bolded words are metaphors that present person as animals).

Table 1 shows that the animals used in the Acehnese metaphors to dehumanize human beings are mostly crocodiles, tigers, birds, goats, buffalos, and insects (i.e., mosquitos, grasshoppers, and flies). Other animals include the mouse deer, monkeys, fish, dogs, or animals with tails.

The animal crocodile is used to dehumanize both male and female, as in buya krueng teudöngdöng, buya tamöng meuraseuki literally means 'local crocodiles only wait and see, while the new crocodiles take the benefits.' This saying contains metaphors that dehumanize people because it describes people with animal buya (crocodiles), which refers to newcomers and locals. This saying is used for various contexts, such as when local people are upset due to the policy that does not benefit local people. It can also mean an urge to remind local people to improve their qualifications to compete with foreigners.

Meanwhile, a crocodile is also specifically used to dehumanize males. The example is in agam buya, which literally means 'a crocodile man.' Hence, the metaphor animalizes the male person, addressed with a crocodile. It is commonly used to conceptualize a male person who likes to woo a female person even with tear and makes a relationship with a girl for entertainment, but he often breaks his promises and leaves her whenever he does not like her anymore. In English, the dehumanizing metaphor 'crocodile' is similar in meaning as in the idiom 'crocodile tears,' which also refers to a person who weeps to express sorrow for the poor disadvantaged but is actually happy. In this metaphoric example, the bad behavior of a man who womanizes is mapped with the bad behavior of a crocodile as a wild predator. 
Table 1

Person as Animal Metaphors in Acehnese

\begin{tabular}{llll}
\hline No. & Metaphors & Source domain & Target domain \\
\hline 1 & Agam buya & crocodile & Male \\
2 & Buya krueng teudöng-döng, buya tamöng meuraseuki & crocodile & Male/female \\
3 & Alaihai rimueng pluek & tiger & Male/female \\
4 & Bek peugö rimueng èh & tiger & Male/female \\
5 & Hanjeut na manök agam laen & cock & Male person \\
6 & Aneuk bubruek adak tagusuek, jiwoe chit lam paya & quail & Male/female \\
7 & Bek gabuek, ji-phö ma jih & (general) bird & Male/female \\
8 & Kamèng keudèe & goat & Female \\
9 & Alaihai kamèng bhok & goat & Male \\
10 & Leumiek tanöh, jikubang keubeu & buffalo & Male/female \\
11 & Jipeugot kah keu keubeu noh & buffalo & Male/female \\
12 & Jamok di luwa keuleumbu & mosquito & Male/female \\
13 & Meunyö hana daruet canggang, daruet blang jeut keu raja & grasshopper & Male/female \\
14 & Lalat mirah & flies & Male/female \\
15 & Akai peulandôk & mouse deer & Male/female \\
16 & Bak bue tajôk bungong & monkey & Male/female \\
17 & Bak-bak karéng ka iduek asoë & dried fish & Male/female \\
18 & Meutemeung asèe deuk ngon èk ciret & dog & Male/female \\
19 & Hana meuho meuiku-iku & animals with tails & Male/female \\
\hline
\end{tabular}

Tigers are employed to dehumanize both males and females. There are two metaphors in Acehnese that use tigers to degrade humans. The first one is the expression of alahai rimueng pluek, which Acehnese people commonly use to show one's anger at a person who has done a bad thing. Semantically, alahai rimueng pluek means 'a tiger that gorges' or an animal that eats a large amount of greedily and does not care for others. In other words, this expression dehumanizes someone negatively as he or she has done a bad deed and is represented as a greedy tiger. The second metaphor with tigers is bek peugö rimueng éh 'do not wake up a sleeping tiger.' This metaphor prohibits disturbing a person with strong power, which is dangerous to the person who disturbs him. This expression is also used when one attempts to intimidate another person. Because of the use of rimueng 'tiger,' this means that a person is animalized. In other words, the person is presented as a strong and petrifying animal.

Some three metaphors found dehumanize human beings by associating them with birds. The birds here are such as cocks, quails, and other birds in general. The metaphor hanjeut na manok agam laen 'there should be no other cocks' is primarily for males. This refers to a man who does not want any other males to be his rival, or in other words, he deems himself the best of the best. If a man is directed with this metaphor, he is typically considered an arrogant man in the Acehnese society. Meanwhile, two other metaphors that use birds can be directed to degrade both males and females. In the proverb aneuk bubruek adak tagusuek, jiwoe chit lam paya (a quail child, even though it has been tamed, it will return to the swamp), the bubruek (quail) is used to refer to a person who leaves the family that has adopted and raised him or her lovingly, but then at the end of the day, he or she will still return to his or her biological parents. In this proverb, the well-known trait of a bird, which is wild, is conceptualized into the target domain of human beings who are naturally inclined to live with their parents. It is expected that we should not rely too much on others even though we have invested many things in them. Whereas in bèk gabuk jipho ma jih 'do not be a busy body or else the mother will fly away' is a reminder to someone not to make problematic situations worse and make them more complicated.

The two metaphors with goats are specifically directed to males and females. The first one is for males, which is kamèng bhok, and it is to refer to a playboy or a man who spends his time enjoying himself with many women who are not his wives. The Acehnese refers to this kind of man as 'a male goat.' Society sees a male goat as an animal that has a high libido to have sex. That is why a man who is conceptualized as a kamèng bhok in Aceh society is similar to a womanizer. The second one if for females, which is kamèng keudèe 'goat at the market'. This metaphor portrays the negative behavior of a female person who lets men touch her before marrying her. This is deemed similar to the goats' behavior in the Acehnese traditional markets in the past. During those times, the market was commonplace for unattended goats to wander about, but they are usually tamed. The goat's concrete concept in the market is locally understood as a tame but unattended goat that can be touched by anyone in the market. Nevertheless, unattended goats are seldom found in most markets in Aceh today due to the state penalties for leaving pets or livestock unattended in public places.

Another animal used to dehumanize human beings are buffalos, and these metaphors are directed for both male and female. The proverb meunyoe leumiek tanöh, jikubang 
keubeu literally means 'if the soil (i.e. ground) is soft, the buffalos will inhabit it'. In Acehnese, the proverb means if a person does not have a strong argument, other people will dominantly influence his or her decision. Therefore, the metaphor depicts the buffalo as a person who can influence a weaker person in making decisions. Whereas jipeugot kah keu keubeu noh means 'you are treated as a logcarrying buffalo.' This saying means a person employed to work hard as labor received no payment or paid little money, i.e., like a slave in the colonial era. In the expression, a person is animalized as a buffalo, a farm animal commonly used by Acehnese people to carry logs in the jungle, hoe the ground, and trample the ground for bricks, among others.

Metaphors that dehumanizes both male and female with insects include mosquitos, grasshoppers, and flies. These insects are typically found in tropical areas, such as in Indonesia. In some parts of Aceh, the people even enjoy fried grasshoppers as snacks. A proverb meunyoe hana daruet canggang, daruet blang jeut keu raja literally means that 'if there are no long leg grasshopper, the rice field grasshopper will become the king.' This metaphorically means that even a weak person can replace a position if the better person does not want to do so. In the proverb, daruet blang 'rice field grasshopper' is referred to as the weak person, and daruet canggang 'long leg grasshopper' is referred to as the better person. In the meantime, the metaphor with mosquitos is jamok di luwa keuleumbu, which literally means 'mosquitos outside of the mosquito net'. In Aceh, especially in villages, it is common that the beds in the house are covered with mosquito nets at night; this is to avoid people being bitten by these insects. The metaphor means an urge to ignore the voices of people talking outside of the system, who does not affect anything to the system. These people are referred to as jamok 'mosquitos' to the Acehnese people because they are disturbing people while resting or sleeping. Then there is lalat mirah 'red fly', which refers to a person who likes to uncover other people's secrets to other people. In other words, the person is a blabbermouth. A red fly is used to describe a red fly, as Acehnese sees this fly as an insect that spread germs from one place to another.

Akai peulandôk literally means the 'mouse deer's mind,' which metaphorically refers to a cunning individual (male or female) in the Acehnese culture. Mouse deer is by nature an animal; hence the metaphor tends to dehumanize the person referred to it. As one of the famous folktales in Southeast Asia (Shepard \& Gamble, 2005), a mouse deer is described as a smart animal. In one of its stories, it was able to delude many crocodiles as its enemies when it wanted to cross a river, and its leg was caught by a crocodile (Wolf et al., 2017). However, this metaphor is somewhat polite in the
Acehnese culture because peulandôk is considered a smart animal in outwitting its enemies.

The saying bak bue tajôk bungong 'a flower given to a monkey' is a negative metaphor that also dehumanizes a male or female. In this saying, a monkey refers to a person who does not take care of the thing given to him or her or cannot use it in the right manner. A monkey is, by nature, an animal that will break the valuable things. To the Acehnese, a flower is a symbol of love; therefore, it is spiteful if someone breaks it. Hence, someone who does not have kindness and love is referred to as a wild animal (i.e. monkey).

Bak-bak karéng iduk asoe literally means 'even dried anchovies have meat.' Metaphorically, this witticism refers to a skinny or thin man or woman deemed impossible to gain weight. Karéng is dried, salty anchovies, and are a vital part of the Acehnese dish. They have a pungent smell. The Acehnese eat them fried or cooked with spices. Since they are dried, there is no chewy meat left to taste, and thus a skinny person who cannot gain weight is denoted as a karéng.

Meuteumeung asèe deuk ngon èk cirét literally means 'the $\operatorname{dog}$ is starving for diarrhea.' Metaphorically, it means meeting two people with the same goal, and it is targeted for a boy and a girl who have met, fell in love, and both intend to marry each other. Finally, the expression hana meuho meuiku-iku also contains an animals' metaphor to refer to both males and females. The $i k u$ 'tail' is certainly not part of the human body; it is part of the animal's body. However, the expression is sometimes used in Aceh to disallow or prohibit a person from going or following another person or people. A person who likes to follow other people around is seen as animals who typically follow other animals around.

The findings of a person as animal metaphors in Acehnese show that most of the dehumanizing metaphors used are the animals that are close to Acehnese people's lives. Barasa and Opande (2017) state that metaphors are created with typical things (living or non-living) familiar to the people in a society. Animals such as buffalos, goats, mosquitos, dogs, fish, goats, and those described in Table 1 are among the animals that the Acehnese people know and interact with daily. Crocodile, cock, and goat (i.e., kameng bhok 'male goat") are animals allied to men. Acehnese people in the past have been familiar with the traits of the animals selected as the sources to describe the target behaviors of a person or people.

\section{Person as inanimate entity metaphors in Acehnese}

There are some 13 metaphors found to be associated with a person as inanimate entity in Acehnese, and they are illustrated in Table 2 (the bolded words are 
metaphors that present a person as an inanimate entity).

Table 2 shows that the inanimate entity metaphors used to dehumanize human beings are woods, tools, liquids, food, and parts of the human body. The term aneuk ulè bara has two meanings, denotative and connotative ones. Denotatively, ulè bara means 'the house roof board head,' a big wooden board to back the roof part in a wooden house. It is not known by all people in Aceh today because many houses have used steel frames. Connotatively, ulè bara is meant as the first-born child in a family, which according to the beliefs of some people in Aceh, has several deficiencies mentally innate. In other words, a person is portrayed as wood, an inanimate, or not human.

Table 2

Person as In-Animated Entities' Metaphors in Acehnese

\begin{tabular}{llll}
\hline No. & Metaphors in Acehnese & Source domain & Target domain \\
\hline 1 & Aneuk ulèe bara & Wood & Male/female \\
2 & Catok brôk & Hoe & Male/female \\
3 & Paneuk antene & Antenna & Male/female \\
4 & Panyöt culöt & Lamp & Male/female \\
5 & Radio meuigo & Radio & Male/female \\
6 & Bubè dua jab, keunoe toe keudèh rab & Trap & Male/female \\
7 & Meukeut'am barang & Goods & Male/female \\
8 & Kameu ie breuh lawet nyoe & Used water of rice washing & Male/female \\
9 & Meunyoe kön ie, leuhöb; meunyoe kön droe, göb & Water, mud & Male/female \\
10 & Alaihai pliek & Pliek (dried and fermented coconut) & Male/female \\
11 & Bubè dua jab & Fish trap & Male/female \\
12 & Boh hate lôn & Heart & Male/female \\
\hline
\end{tabular}

Catok brôk literally means a broken hoe. However, in the Acehnese language, people often use it to mean a person who behaves like a hoe that hoes and pulls the soil for itself, without caring for others. In other words, this metaphor is used to conceptualize a selfish person. In this example, the person conceptualized as catok brôk is dehumanized as an animated thing/tool.

Paneuk antena literally means a short antenna. However, the expression is commonly used to denigrate a person for his/her uncleverness. A human is presented as non-human because the antenna is usually for radio, mobile phone, or TV. If it is too short, it will not be able to detect channels of programs. In short, in this example, a human is presented as an electronic device.

Panyöt culöt is a kind of oil lamp whose axis is made of used cloth used in Aceh before the era of electricity. When turned on, the oil lamp will illuminate its surroundings, but leave much black soot to itself and make it dirty. However, in Aceh, it refers to a person who talks about other people's badness, regardless of his/her badness. It clearly shows an inanimation of a person in the metaphor.

The phrase radio meuigö also contains a metaphor that dehumanizes people. The slang radiô meuig ö, if translated literally means radio with teeth. Metaphorically, it means a message delivered from mouth to mouth, which is not easy to validate. In this slang, a person is presented as an animate thing/radio.

Bubè dua jab, keunö to keudeih rab is also a dehumanizing metaphor in a proverb. Bubè dua jab means a two-way fish trap; this is intended for a person who takes benefits from two opposing groups of people. In this case, a person is negatively presented as a thing or non-human. In Aceh society, it is suggested that we not tell secrets to this kind of person because he cannot be trusted.

Meukeutam barang is frequently mostly done by young people in Aceh to refer to a good looking or smart person. Meukeutam is actually the sound emanating from a hammer hit on the wood, which in this case, means good or even best. Barang 'goods' is used here to refer to a person, like a girl or a man. Hence, when someone says meukeutam barang, it means a beautiful girl or a handsome boy or guy; a person who has high quality.

Kameu ie breuh lawet nyoe is an expression commonly given when a person addresses his or her friend. Kameu ie breuh lawet nyoe literally means '(your face has) used rice water recently'. However, this metaphorically means that the person addressed has looked physically better lately. Perhaps this is because rice is the main dish of the Acehnese meals. Before being cooked, the rice is washed about three times with water. Many Acehnese do not throw away the water used to wash the rice; some used it to water their plants because they believe this water has now contained vitamins and minerals for growing the plants. This metaphor indicates that when a person is looking physically better than before, it is as if he is like who plant that has grown well due to the water used from washing rice. This metaphor also dehumanizes a person as it conceptualizes the human face using water to wash rice.

Meunyoe kön ie, leuhöb; meunyoe kön droe, göb literally means if not water, (it is) mud; if not us, (they are) others. The metaphor ie (water), is used to represent human beings droe 'us' and leuhop 'mud.' This saying contains 
dehumanizing metaphors that dehumanize people with inanimate things, i.e., water. In practice, Acehnese people intend to say that we should not rely (too much) on other people for our well-being. Other people might do lie to us or do other bad things. Therefore, we need to be self-reliant in this life.

Alaihai pliek is an expression used in Aceh, which also presents a person as a kind of food ingredient. Pliek is usually developed manually from the coconut by the Acehnese. It is grated coconut and dried for several days to result in pliek with good taste, but not good in smell. It is physically dark brown. That is why pliek is used to describe a person who is bad looking.
The metaphor boh haté is literally translated into 'the heart of a fruit'. However, Acehnese people commonly use it in their daily life, especially in expressing their love for their beloved ones, such as their children. It is also used by a couple of lovers to express their love for each other. However, the meaning is the beloved person. Despite the positive meaning, it dehumanizes a person as it has presented a person as a thing, not human.

\section{A person as plant metaphors in Acehnese}

Several metaphors are associated with a person as plants in Acehnese, as illustrated in Table 3 (the bolded words are metaphors that present person as plants).

Table 3

Person as Plant Metaphors in Acehnese

\begin{tabular}{lll}
\hline Metaphors in Acehnese & Source domain & Target domain \\
\hline Böh ceudieng & Rice & Male/female \\
Padé jum & Wet rice & Male/female \\
Böh lam ôn & Fruit & Male/female \\
Teubè kầy & Sugar cane & Male/female \\
\hline
\end{tabular}

From Table 3, among the terms used to refer to a person or a group of people in Acehnese language is boh ceudieng. Literally, boh ceudieng means the rest of the rice on straws that grow by themselves later after being harvested. It was prevalent in Aceh that rice straw is cut half. Some are left uncut, which then grow their leaves and yield rice again. Most people do not care about ceuding because it is not much, but some do. That is why when a person or a group of people is deemed to lack some abilities, and they are labeled böh ceudieng, it means not to expect much from them.

Pade jum (wet rice) is also often heard from the mouths of older adults in Aceh. It is metaphorically used to conceptualize a person's behavior that is not dynamic in his or her life. Such a person cannot move on as in the wet rice case in a sack that is hard to be moved because it is cumbersome. Hence, that kind of person is dehumanized as wet rice.

The saying boh lam ôn is also a metaphor that dehumanizes a person. Boh lam ôn means a fruit covered in the tree leaves, saved from being disturbed by insects such as beetles. Boh (fruit) am $\hat{o} n$ in this context refers to a girl who has not been touched by a man. She is a virgin or a girl who stays a virgin until marriage. So, she is deemed a pure girl. This saying is commonly used when a young man is looking for a girl for his wife and is then introduced to a girl who is boh lam ôn. This dehumanization is, thus, denotes positivity for the female.

\section{DISCUSSION}

This study has explored dehumanizing metaphors used daily by the Acehnese people in Indonesia, and whether these represent male and female persons. The findings indicate that many primary metaphors used daily in Aceh are dehumanizing, representing male and female persons. Most of the metaphors used animals or things used as the sources are the ones that are closed to their daily lives, such as cows, crocodiles, quails, buffalos, goats, tigers, birds, and insects. Besides, the metaphors use a trap, radio, antenna, rice, et cetera. The abstract human beings' attributes are presented with the animals' behaviors, such as the tiger's wild and ferocious behavior, to conceptualize a person's bad behavior. Intriguingly, most of the dehumanizing metaphors apply for either a male or a female person. Moreover, the use of locally found animals and other inanimate entities in the dehumanizing metaphors suggests that the meanings intended from the metaphors are relevant to the Acehnese people's belief towards nature and how it is related to human beings. Concerning this, Su (2002) asserted that their metaphors shape people's thoughts in their daily lives.

To some degree, the findings also corroborate previous research findings on the dehumanizing metaphors (e.g., Barasa \& Opande, 2017; Musolff, 2015; O’Brien, 2009; Prażmo, \& Augustyn, 2020; Usman, 2017). All the abstract concepts used to describe the concretely perceivable concepts in metaphors are usually are close to the people's existence and surroundings. In the examples of the dehumanizing metaphors in Aceh, such as böh ceudieng, padé jum, böh lam ôn, and teubè kâ̂y, all are agricultural products in the dehumanizing metaphors in the Acehnese language are inseparable from most people's occupations in Aceh in the past, and even those until today are farmers, especially rice farmers. Similarly, to describe bad things about 
a person, the concepts of animals are used. On the contrary, in the Kenyan context, Barasa and Opande (2017) found that people used animals as the concepts to describe women in Bukusu and Gusii proverbs. A similar thing also happened in Japan context (Prażmo, \& Augustyn, 2020), where people who do not conform to conventional societal roles are labeled with animals.

In the political context, Musolff's (2015) research found that the UK politicians used "parasites" to describe the immigrants to persuade people of the country that immigrants need to be rejected from entering the country. O'Brien (2009) also found the use of dehumanizing metaphors in denigrating a marginalized group of people. In a nearly similar vein, in Usman's (2017) research findings, the local politicians used the terms "traitor(s)" and "others" to describe those who were politically not on their sides. All these findings suggest that many dehumanizing concepts are used to describe people negatively through metaphors, depending on how they believe that they understand the concepts' meaning.

However, nearly all of the dehumanizing metaphors are Aceh culture-specific, whose meanings are only understood by the people who share similar cultures (Lakoff \& Johnson, 1980). These culture-specific metaphors indirectly teach Acehnese society how to behave according to their beliefs and traditions (Yusuf \& Yusuf, 2014). From the data, catok brôk, which means a broken hoe, for instance, is only for the local people. As mentioned earlier, many Acehnese are farmers; thus, catok 'hoe' is a tool used to plow the soil for planting. Hence, a rusty or broken (i.e., brôk) hoe is useless. A person, either male or male, who has bad behavior, selfish, is then associated with a rusty and broken hoe. However, some of them, like boh lam ôn, which literally means a covered fruit in the tree leaves, are now less used by the younger Acehnese, or the millennial generation. This suggests that the millennial generation has gradually embraced a different culture from that of the old generation, even though they live in Aceh.

Furthermore, most metaphors used in Aceh are genderless, and this should not be understood in isolation. Acehnese is a genderless language that has no distinctions of grammatical gender. No categories are requiring morphological agreement between nouns and associated pronouns, adjectives, articles, or verbs. Furthermore, this may also suggest that people in Aceh do not linguistically discriminate against people, both male, and female. This is probably because of the Islamic teachings that the Acehnese people embrace. Therefore, the context of cultures and traditions in Aceh are mostly influenced by Islamic values (Habiburrahim et al., 2020). The teachings require people to treat each other equally, regardless of their gender, ethnics, et cetera.

\section{CONCLUSION}

Grounded by the Conceptual Metaphor Theory, this study's findings showed that the metaphorical expressions in the Acehnese culture that dehumanize people mostly use animals' concepts, and the rests are of inanimate entities and plants. Hence, most dehumanizing metaphors used in the Acehnese language use animals as the source domain. A variety of animals used in Acehnese's metaphorical expressions range from small to big ones, and tamed and wild. These animals are commonly found in Acehnese daily life, such as grasshoppers, flies, and cows. However, not all metaphors that use animals have negative meanings; some also denote positivity. These metaphors remind society about their behavior and how they should interact with other people. Another suggestion regained in the data is that most of the Acehnese's dehumanizing metaphors are for everyone, regardless of their age or gender.

However, it is also important to note that the dehumanizing metaphors examined are the metaphors that have been transferred from generation to generation in Aceh society. Other types of metaphors, such as creative metaphors, are beyond this study. Therefore, future studies need to address many types of metaphors.

\section{REFERENCES}

Adams, S. M., Case, T. I., Fitness, J., \& Stevenson, R. J. (2017). Dehumanizing but competent: The impact of gender, illness type, and emotional expressiveness on patient perceptions of doctors. Journal of Applied Social Psychology, 47(5), 247-255. https://doi.org/10.1111/jasp.12433

Azwardi. (2012). Ungkapan bereferen binatang dalam Bahasa Aceh dialek Peusangan [Terms with animal reference in Acehnese of the Peusangan dialect]. Mentari, 15(2), 178-193. http://ejournal.unmuha.ac.id/index.php/mentari /article/view/115

Barasa, M., \& Opande, I. (2017). The use of animal metaphors in the representation of women in Bukusu and Gusii proverbs in Kenya. Africology: The Journal of Pan African Studies, 10(2), 82-108.

http://41.89.196.16:8080/xmlui/bitstream/hand le/123456789/312/The\%20use\%20of\%20anim al\%20Metaphors.pdf?sequence $=1 \&$ is Allowed $=\mathrm{y}$

Creswell, J. W. (2014). Research design: Qualitative, quantitative, and mixed method approaches $\left(4^{\text {th }}\right.$ ed.). Sage Publications.

Daane, A. R., Haglund, J., Robertson, A. D., Close, H. G., \& Scherr, R. E. (2018). The pedagogical value of conceptual metaphor for secondary science teachers. Science Education, 102(5), 1051-1076. https://doi.org/10.1002/sce.21451 
Fata, I. A., Yusuf, Y. Q., \& Sari, L. N. (2018). Figuring the figures of speech in Acehnese traditional song lyrics. Humanities Diliman, 15(1), 30-56.

https://journals.upd.edu.ph/index.php/humaniti esdiliman/article/view/6135

Habiburrahim, H., Rahmiati, Z., Muluk, S., Akmal, S., \& Aziz, Z. A. (2020). Language, identity, and ideology: Analysing discourse in Aceh sharia law implementation. Indonesian Journal of Applied Linguistics, 9(3), 599-607. https://doi.org/10.17509/ijal.v9i3.23210

Haslam, N. (2006). Dehumanization: An integrative review. Personality and Social Psychology Review, 10, 252-264. https://doi.org/10.1207\%2Fs15327957pspr100 3_4

Jamrozik, A., McQuire, M., Cardillo, E., \& Chatterjee, A. (2016). Metaphor: Bridging embodiment to abstraction. Psychonomic Bulletin \& Review, 23(4), 1080-1089. https://doi.org/10.3758/s13423-015-0861-0

Keraf, G. (2004). Diksi dan gaya bahasa [Language and diction]. PT Gramedia Pustaka Utama.

Lakoff, G. (1995). Metaphor, morality, and politics, or, why conservatives have left liberals in the dust. Social Research, 62(2), 177-213. https://escholarship.org/uc/item/7vp15113

Lakoff, G., \& Johnson, M. (1980). Metaphors we live by. University of Chicago Press.

Li, C. (2019). Metaphors and dehumanization ideology: A critical analysis of the multimodal representation of women in advertising. Chinese Semiotic Studies, 15(3), 349-377. https://doi.org/10.1515/css-2019-0021

Lowery, D. (2013). Helping metaphors take root in the EFL classroom. English Teaching Forum, 51(1), 12-17.

https://americanenglish.state.gov/files/ae/resou rce_files/51_1_4_lowery.pdf

Musolff, A. (2015). Dehumanizing metaphors in UK immigrant debates in press and online media. Journal of Language Aggression and Conflict, 3(1), 41-56.

https://doi.org/10.1075/bct.93.02mus
O'Brien, G. V. (2009). Metaphors and the pejorative framing of marginalized groups: Implications for social work education. Journal of Social Work Education, 45(1), 29-46. https://doi.org/10.5175/JSWE.2009.200700028

Prażmo, E. M., \& Augustyn, R. (2020). Parasites, herbivores and dried fish: Dehumanising metaphorical blends in Japanese. GEMA Online Journal of Language Studies, 20(2), 148-167. https://doi.org/10.17576/gema-20202002-09

Shepard, A., \& Gamble, K. (2005). The adventures of mouse deer: Favorite folk tales of Southeast Asia. Skyhook Press.

Steen, G. J. (2002). Identifying metaphor in language: A cognitive approach. Style, 36(3), $386-406$.

$\mathrm{Su}$, L. I. (2002). What can metaphors tell us about culture? Language and Linguistics, 3(3), 589613.

Thibodeau, P. H., Hendricks, R. K., \& Boroditsky, L. (2017). How linguistic metaphor scaffolds reasoning. Trends in Cognitive Sciences, 21(11), 852-863. https://doi.org/10.1016/j.tics.2017.07.001

Thibodeau, P. H., Matlock, T., \& Flusberg, S. J. (2019). The role of metaphor in communication and thought. Language and Linguistics Compass, 13(5), 1-18. https://doi.org/10.1111/lnc3.12327

Usman, J. (2017). Metaphors in the ex-GAM's political discourses during pre-public elections in Aceh. Englisia Journal, 4(2), 116-130. https://doi.org/10.22373/ej.v4i2.1667

Wolf, H. V., Ling, L. W., Pillai, S., \& Phillip, A. (2017). The mousedeer and the crocodiles: A Malaysian folktale in 111 languages. University of Malaya Press.

Yusuf, Y. Q., \& Yusuf, Q. (2014). Contemporary Acehnese cultural prohibitions and the practice of mystical threats. Kemanusiaan: The Asian Journal of Humanities, 21(2), 21-53. http://web.usm.my/kajh/vol21_2_2014/KAJH $\% 2021(2) \% 20$ Art\%202(21-54).pdf 